\title{
Are you digitized? Ways to provide motivation for ELLs using digital storytelling
}

\author{
Yoon, Tecnam $\bowtie$ \\ University of Massachusetts, Amherst, USA (tyoon@educ.umass.edu)
}

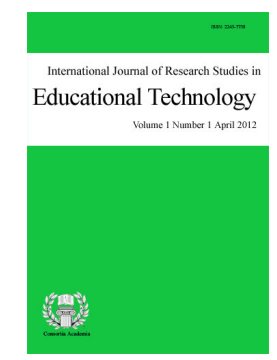

Accepted: 5 September 2012

ISSN: $2243-7738$ Online ISSN: 2243-7746

OPEN ACCESS

\section{Abstract}

The purpose of this paper is designed to explore the effects of using digital storytelling in after school English classroom on Korean ELL learners' attitudes; and perception toward learning in English. In a public elementary school located in Eastern Kyunggi province in South Korea, 32 ELL learners in the 5th grade participated in 12-week study experiencing digital storytelling in English class. 'Digital storytelling' as a primary teaching and learning resource was introduced and adapted, which had been designed and developed by the researcher. And to figure out the impact and effect of digital storytelling, a mixed research method was conducted for looking to students' response. Students' self-evaluation report and lecture review report gathered for data analysis along with quantitative data which were pre-/post-survey on the change of students' learning attitude and reading comprehension. The findings showed that the potential benefits of digital storytelling brought positive effects on the 5th grade ELL students' attitudinal changes in learning English by helping them to have deeper understanding of the lesson, which led their voluntarily active class participation. The results also revealed that digital storytelling made students engaged in the content of the story not only by promoting motivation and interest, but also by providing confidence in learning English.

Keywords: digital storytelling; computer technology; English language learners; L2 motivation; perceptions 


\section{Are you digitized? Ways to provide motivation for ELLs using digital storytelling}

\section{Introduction}

Now, as information communication technology has dramatically transformed our society into a virtual space in which digital tools and devices are ubiquitous, it is no longer surprising in our daily life to see people navigating their smart phones or electronic devices to acquire a new knowledge. Because of the rapid development of ICT, the form of delivered information to us also has undergone profound changes from in a paper format to a virtual one. The area of foreign language teaching and learning is not an exception. Today's students who are called 'Digital Natives' (Pyrensky, 2001a, 2001b) are of a keen interest in using digital multimedia devices, which are inspiring school teachers to consider the possibility of converting and expanding their traditional teaching strategy into the virtual ubiquitous environment where students are constantly exposed (Burmark, 2004; Burn \& Reed, 1999; Chu, 1995; Cradler et al., 2002; Pierson, 2001; Pritchard, 2004).

In fact, young students of the digital era are constantly immersing themselves in up-to-date digital electronic devices such as smart phones, tablet PCs, e-book readers and many more. As they take a great interest in such tools, school teachers are also encouraged to teach utilizing multimedia (Byrnes \& Wasik, 2009; Vincent, 2006). The reality of this phenomenon encourages particularly non-native English teachers in ESL/EFL situations to use the computer- and digital- assisted tools and devices as a way of reinforcing students' negative attitudes toward foreign language learning. In English language classroom, for example, many of the teachers are using PowerPoint Presentations in their lessons, and a variety of educational software applications, CDs, DVDs, and etc, in order to facilitate their lessons. In the age of virtual environment, as Tsou et al. (2006) stressed, integrating computer technology with foreign language teaching and learning is remarkably useful and necessary to preparing ELL students to function in a rapidly-changing world.

\section{Digital Storytelling}

\subsection{What is Digital Storytelling?}

Traditionally, storytelling itself is regarded as the oldest form of education, and it has been a form of communicating throughout human history, and has been a way to educate children to be literate. Storytelling 'digitally', not 'orally' is called digital storytelling which is a kind of practice of using computer- and multimedia-assisted tools in order to tell stories to others. In digital stories, there are a set of multimodal aspects and components included such as visual images, written texts, recorded audio narration, music/sound, and video clips/segments. Lambert (2002) defined digital storytelling as follows.

"It begins with the notion that in the not too distant future, sharing one's story through multiple medium of imagery, text, voice, sound, music, video and animation will be the principal hobby of the world's people."

In other words, the concept of digital storytelling is focused on human narratives using images, narration and music to frame our memories as powerful stories (Bull \& Kajder, 2004; Robin, 2008; Sadik, 2008). Table 1 simply shows several different points between oral and digital storytelling.

With regards to the subject as with a traditional way of oral storytelling, the topic of digital storytelling may vary but for the medium which combines diverse multimedia components such as graphics, audio, video, animation and so on. And a sampling of story topics may include from the telling of a personal story to certain historical events (Judge et al., 2006; Kajder et al., 2005; Tucker, 2006). 
Are you digitized? Ways to provide motivation for ELLs using digital storytelling

Table 1

Oral storytelling vs. Digital storytelling

\begin{tabular}{lll}
\hline \multicolumn{1}{c}{ Items } & \multicolumn{1}{c}{ Oral Storytelling } & \multicolumn{1}{c}{ Digital Storytelling } \\
\hline Time of Advent & thousands ago & $\begin{array}{l}\text { in 1994 by Atchley \& Lambert at the Center } \\
\text { for Digital Storytelling }\end{array}$ \\
\hline Type of main style & human voice and gesture & $\begin{array}{l}\text { multimedia components } \\
\text { (video, image, sound, etc) }\end{array}$ \\
\hline Contents delivering & verbal communication & $\begin{array}{l}\text { information devices } \\
\text { (PCs, Tablets, etc.) }\end{array}$ \\
\hline Data Forms & typically painted or printed paper & stored electronically in digital form \\
\hline Way of learning & verbal delivery-centered / one-way & $\begin{array}{l}\text { multiple way delivery / Interaction \& } \\
\text { collaboration }\end{array}$ \\
\hline Main character & Ppeaking \& listening & $\begin{array}{l}\text { to unfold a highly sensory experience with } \\
\text { narrative voice, images, sound, and music } \\
\text { into illuminated understandings }\end{array}$ \\
\hline
\end{tabular}

\subsection{Digital storytelling in Foreign Language Learning}

In L2 learning, digital storytelling can indeed be a good vehicle to increasing language performance in that it has the potential to provide motivation to students by engaging in reflective learning because of the up-to-date ICT technologies and multimedia functions, which can appeal to young generations. In particular, using visual and audio effect can be the biggest difference between digital storytelling and oral one (Banaszewski, 2002; Lowenthal, 2008; Ohler, 2006; Sylvester \& Greenidge, 2010).

For instance, in reading/writing session, ELL learners can have more creative opportunities if provided with sounds, music, graphics, images and animations which expand them to express their creativity. Besides, students can share their own stories through digital storytelling in ways other than just plain text, so that they can think more creatively and critically. In addition, learners are expected to have more chances for collaboration and cooperation work with each other through digital storytelling which helps them gain social and cognitive development through such sharing experiences. In English class, it is also expected that ELL learners can develop their listening and speaking skills as well as vocabulary enhancement (Kajder, 2006; Marsh, 2006; Ware, 2006).

\subsection{Ten principles of digital storytelling}

In terms of adopting and using digital storytelling in the classroom, teachers are encouraged to consider the ten principles as to how digital storytelling can contribute in students' learning in ESL/EFL context. They can be simply called 'I AM TOP CAMP' (Interactive-Authentic-Meaningful-Technological-Organized-ProductiveCollaborative-Appealing-Motivating-Personalized) which are enumerated below.

> Interactive: as digital story is shared with each other, it is possible for student(s)-student(s), student(s)-teacher, the whole class-teacher to have continuous interaction during the learning process.

$>$ Authentic: students can create and share their personally meaningful story with others.

$>\quad$ Meaningful: digital story encourages students to become more conscious of the ability to tell their real story which catches the attention of audience.

$>$ Technological: students can gain experience with dealing with digital devices and become more 
proficient at the technical aspects in making their own story.

$>\quad$ Organized: digital devices helps student to organize their digital stories by creating, editing, add and deleting.

$>\quad$ Productive: students can make their own voice, and produce their desired outcome, through their juxtaposition with visuals, recorded narratives and sounds which deliver their intended message

$>$ Collaborative: by sharing each other, digital story helps students to work collaboratively as a team.

$>$ Appealing: digital story provides a pleasure of learning more than any other factors. Students are expected to gain high academic motivation, engagement, and achievement for further learning.

$>$ Motivating: digital story allows students to gain personalization of the learning experience by increasing motivation.

$>\quad$ Personalized: digital story also includes from the telling of personal stories to any topic related to their life.

\section{Research Method}

This current study was designed for young ELL learners to use digital storytelling in after school English class. The research was carried out for 12-weeks with 32 elementary students from two classes of the fifth grade in a public elementary school in Korea. In English class, digital storytelling instruction was applied, and the learners were asked to do with digital storytelling activities, as opposed to being asked to do so with a teacher who directed storytelling with a storybook. To investigate the effect of digital storytelling, a mixed method approach was employed by collecting, analyzing, and integrating data both quantitatively and qualitatively. Data triangulation was then administered in order to cover diverse viewpoints or standpoints and to validate confidence in the ensuing findings.

\subsection{Research questions}

The purpose of the study aims to investigate the effects of digital storytelling in after school English class and how it affects the change of Korean young ELL learners' attitudes and perception toward learning in English. Thus, the research questions are as following:

$>$ How does digital storytelling work for the improvement of reading ability in young ELL learners?

$>\quad$ In which ways does digital storytelling affect the changes of young ELL learners' attitude in EFL

English reading class?

\subsection{Research Subjects}

There were total 32 Fifth Grade ELL learners participants from Eastern Kyunggi Province, South Korea. The 15 boys and 17 girls were at the age of twelve enrolled in a public elementary school in 2012. The school was located in former industrial midsize city. And all the participants reported that their home language is not English. The main reason for choosing the fifth grade student was that most of the participants were skillful enough to use a computer and type sentences in English. In South Korea, students usually start to learn English and computer as a required subject from the third grade. 
Are you digitized? Ways to provide motivation for ELLs using digital storytelling

Table 2

Details of research participants

\begin{tabular}{|c|c|c|}
\hline \multicolumn{2}{|c|}{ Items } & Value \\
\hline \multicolumn{2}{|c|}{ Primary language in class } & Korean \\
\hline \multicolumn{2}{|c|}{ Primary study materials } & digital story \\
\hline \multicolumn{2}{|c|}{ Lesson flow } & interactive (S-T/S-S/C-T) \\
\hline \multirow{2}{*}{ Participants } & boys & 15 \\
\hline & girls & 17 \\
\hline Total number & & 32 \\
\hline
\end{tabular}

\subsection{Research Instruments}

Participants were given two pre-/post- tests to figure out any changes in English reading ability. Later, a paired-sample t-test was performed with the results, using an initial reading attitude questionnaire. It was administered at the beginning and end of the research to ascertain any possible attitude changes. Plus, pre-/post-survey was also administered to find out the change of the affective domains towards English learning. It consisted of 12 questionnaires that has been used to measure the degree, and has been designed using a 1-5 Likert scale (strongly disagree to strongly agree). Table 3 below shows questionnaires for the affective domain.

Figure 1. A
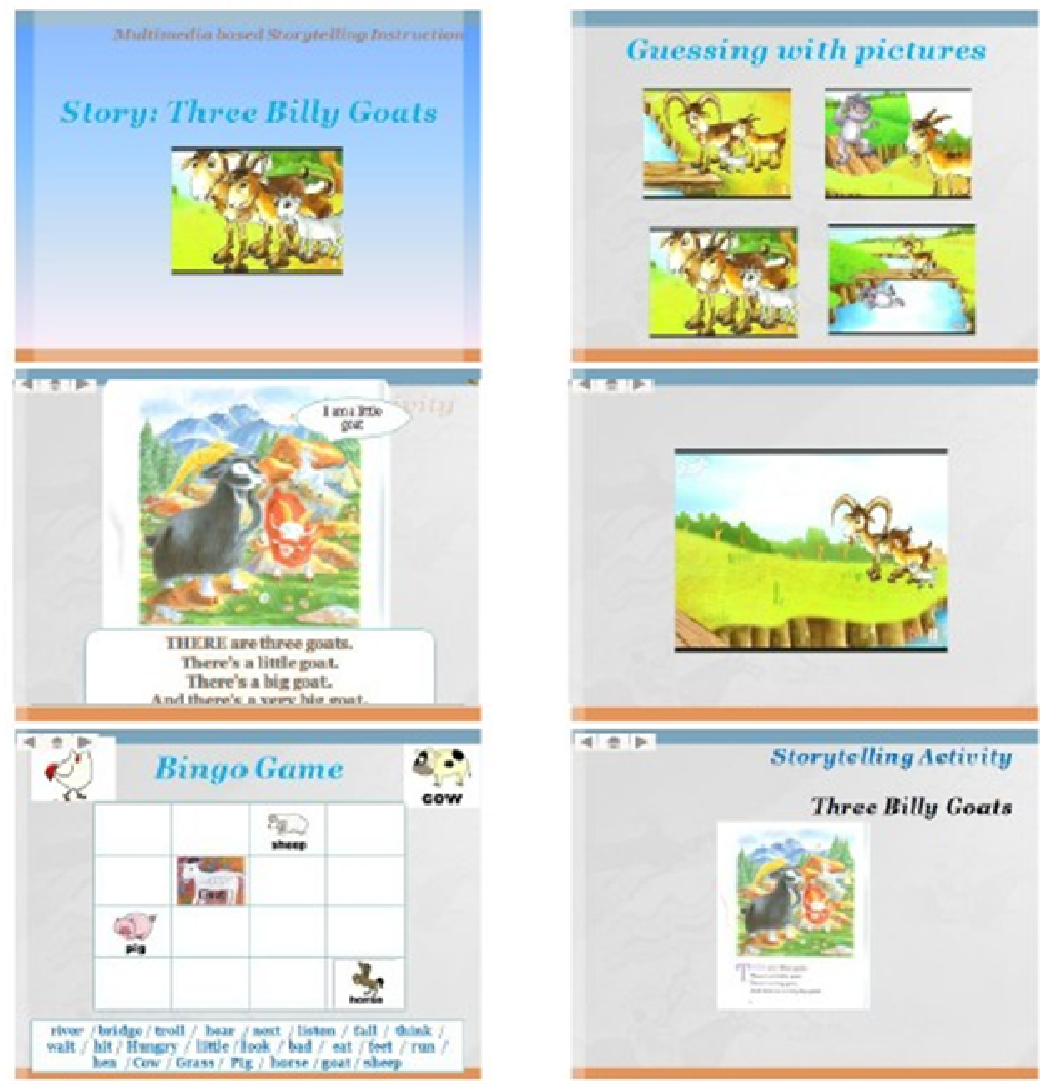

of Digital Storytelling

Sample work

In addition to quantitative data, students' lecture review report was employed after completing the study using digital storytelling in order to understand how students felt. The lecture review report shown as below is composed of three parts: 1) thoughts on digital storytelling, 2) efficacy on digital storytelling, 3) necessity of digital storytelling. 
Yoon, T.

Table 3

Lecture review report on digital storytelling

Date:

Name:

1. What are your overall thoughts on digital storytelling?

2. How do you think about English learning using digital storytelling?

3. Do you think digital storytelling is a good way in studying English? Why? If not, why do you think so?

And at the end of the research, a self-evaluation sheet was provided to students, instead of conducting interviews with all participants. It was also composed of 1-5 Likert scale (strongly disagree to strongly agree), including four main components such as interest, learner participation, understanding, and self-confidence.

\section{Table 4}

A self-evaluation sheet on digital storytelling

Date:

Name:

\begin{tabular}{|c|c|c|c|c|c|c|}
\hline \multirow{2}{*}{ Category } & \multirow{2}{*}{ Content } & \multicolumn{5}{|c|}{ Evaluation } \\
\hline & & 5 & 4 & 3 & 2 & 1 \\
\hline Interest & $\begin{array}{l}\text { I enjoyed learning English using digital } \\
\text { storytelling. }\end{array}$ & & & & & \\
\hline Participation & I participated in class actively & & & & & \\
\hline Understanding & $\begin{array}{l}\text { I understood the story and comprehended } \\
\text { the overall objects. }\end{array}$ & & & & & \\
\hline self-confidence & $\begin{array}{l}\text { I could read words and sentences in the } \\
\text { digital story. }\end{array}$ & & & & & \\
\hline
\end{tabular}

1. What was your favorite activity?

2. How do you like it?

\section{Results and Discussion}

\subsection{Results of the reading comprehension scale and attitude change}

The reading comprehension test was administered before and after the experiment using digital storytelling. As shown in Table 5, there was a difference in the highest and lowest scores, and the means on the reading comprehension after digital storytelling has been adapted. Thus, it can be concluded that digital storytelling had positive effects on the improvement of students' reading ability.

\subsection{Results of the attitude change}

Next, table 6 shows the results from the questionnaire asking about participants' opinions towards digital storytelling in after school English class. They were encouraged to choose the degree agreement in 1-5 Likert 
scale. The results were then interpreted as below.

The results from the quantitative data below indicate that the participants had positive attitude change towards digital storytelling in this experiment research. They strongly agreed that digital storytelling made them engaged in the content of the story by gaining motivation and interest. Besides, participants answered that they had more confidence in learning English in that digital storytelling offered them a fun and pleasant educational experience. In particular, as digital storytelling made them feel less worried and the classroom atmosphere more enjoyable, it was no doubt that student came to like English study more.

Table 5

Result of reading comprehension test

\begin{tabular}{lcccccc}
\hline \multicolumn{1}{c}{ Result } & Total scores & Highest score & Lowest score & M & SD & $t$ \\
\hline Pre-test & 30 & 18 & 6 & 12.6 & 4.91 & $13.62 * *$ \\
Post-test & 30 & 25 & 9 & 18.5 & 5.00 & \\
\hline
\end{tabular}

Table 6

Result of attitude change with digital storytelling

\begin{tabular}{|c|c|c|c|c|}
\hline Opinions & M & $S D$ & $t$ & Sig. \\
\hline 1. Digital storytelling makes me curious about the story. & 3.73 & 0.78 & 1.53 & 0.13 \\
\hline $\begin{array}{l}\text { 2. Digital storytelling makes me more interested in reading } \\
\text { process and activity. }\end{array}$ & 3.97 & 0.76 & 0.954 & 0.34 \\
\hline 3. Digital storytelling makes me understand the story better. & 3.90 & 0.66 & 0.770 & 0.44 \\
\hline $\begin{array}{l}\text { 4. Digital storytelling makes me confident when I was assigned } \\
\text { to read. }\end{array}$ & 3.87 & 0.73 & 0.791 & 0.43 \\
\hline $\begin{array}{l}\text { 5. Digital storytelling provides me with the opportunity to think } \\
\text { creatively and critically. }\end{array}$ & 3.70 & 0.65 & 1.52 & 0.84 \\
\hline $\begin{array}{l}\text { 6. Digital storytelling makes me know more from sharing ideas } \\
\text { with classmates. }\end{array}$ & 4.03 & 0.81 & 1.22 & 0.23 \\
\hline 7. Digital storytelling makes English learning fun and pleasant. & 3.87 & 0.73 & 0.386 & 0.76 \\
\hline 8. Digital storytelling makes me more engaged in the lesson. & 3.90 & 0.71 & 0.706 & 0.48 \\
\hline 9. Digital storytelling makes me happy with reading activity. & 3.93 & 0.69 & $4.69 * *$ & 0.01 \\
\hline $\begin{array}{l}\text { 10. Digital storytelling makes the class atmosphere more } \\
\text { enjoyable. }\end{array}$ & 3.77 & 0.57 & $3.04 * *$ & 0.01 \\
\hline 11. Digital storytelling makes me like English study more. & 3.90 & 0.71 & 0.954 & 0.34 \\
\hline 12. Digital storytelling makes me familiar with the story. & 3.93 & 0.64 & 0.726 & 0.47 \\
\hline
\end{tabular}

\subsection{Result of Lecture Review Report}

In order to find out students' attitudes and feelings about digital storytelling, instead of conducting formal interviews, completing a lecture review report was given to participants twice throughout the research. Similar answers from students were then categorized into 5 categories that explained how they felt on digital storytelling.

Participants agreed that one of the most beneficial effects on digital storytelling was helpfulness. By gaining a sense of satisfaction and confidence, students were strongly motivated, which aided them to have a desire for further English learning. Based on some excerpts1 from students' reports2 below, it became much clear why they felt satisfied with digital storytelling.

\footnotetext{
1 Students lecture reviews were originally written in Korean, and then translated into English by the researcher.

${ }^{2}$ Pseudonym was used to conceal students' identity.
} 
“...At first, I was worried, because I am not good at making a story. But it was fun to work with my friends. I was able to finish my work and present it in front of the whole class. I loved to share what I did with my classmates..." (Eunkyung, March 21, 2012)

“... I like to use the visual images in the story, and I can easily understand what it means. I also record my voice to narrate my own story. To choose music and sound is also very interesting. I want to make more stories and then share them with friends...." (Jeongja, April 12, 2012)

“... I have been reading books alone, but digital story was very fun to make, to read and to share with. I can remember the words and the stories longer, and to use a computer and programs in the classroom is also a pleasant learning experience to me..." (Eunseok, April 20, 2012)

As described above, students enjoyed English reading class using digital stories including multimedia components. It was obviously different from a traditional reading class depending on the paper storybooks, and the bottom line is that students were able to have motivation for learning in English class.

Table 7

Categories of Students' Lecture Review

\begin{tabular}{llc}
\hline \multicolumn{1}{c}{ Category } & \multicolumn{1}{c}{ Review Comments } & $n(\%)$ \\
\hline helpfulness & 1. Digital storytelling is helpful to overall English learning & $26(81 \%)$ \\
pleasure & 2. Digital storytelling makes reading class fun. & $22(69 \%)$ \\
interest & 3. Digital storytelling provides more interest in learning English. & $18(56 \%)$ \\
motivation & 4. I want to study English more with digital storytelling & $17(53 \%)$ \\
necessity & 5. Digital storytelling is necessary in English class. & $15(47 \%)$ \\
\hline
\end{tabular}

\subsection{Result of students' self evaluation sheet}

During the treatment of digital storytelling class, student was asked three times to fill out self-evaluation sheet for the purpose of seizing the changes of affective domain. Self-evaluation sheet consisted of 4 main contents which were interest, participation, understanding, self-confidence for learning English using digital storytelling. Table 8 shows the result of students' responses.

Table 8

Result of Students' Self Evaluation

\begin{tabular}{lccc}
\hline \multicolumn{1}{c}{ Contents (100pts) } & \multicolumn{2}{c}{ Number of times } \\
\hline Interest & 1 & 2 & 3 \\
Participation & 80 & 88 & 98 \\
understanding & 69 & 82 & 95 \\
self-confidence & 71 & 79 & 90 \\
\hline
\end{tabular}

As shown at Table 8 above, students' interest and understanding for digital storytelling lesson have escalated over time. They got more involved in the lesson using digital storytelling which triggered comparatively active participation in the class and made them gain self-confidence, lowering down anxiety in learning English. To sum up, including digital storytelling as part of reading and writing instruction helped ELL student learning considerably enhanced, clarifying that digital story was very effective in the sense that the students were all engaged in, and their attention was focused. As Mayer (2003) stressed, active engagement in the class helped the students construct their knowledge and organized information into meaningful learning. 


\section{Conclusions and implications}

This research study was designed to explore the effects of using digital storytelling in elementary school English classroom and to evaluate the changes of Korean ELL learners' attitudes and perception toward English learning. 32 ELL learners in the 5th grade enrolled in a public elementary school in Eastern Kyunggi province, South Korea participated in 12-week research study with digital storytelling in after school English class. In order to seize the impact and effect of digital storytelling, a mixed research method was administered in observing students' changes and responses.

The results indicate that 1) digital storytelling showed positive effects on the improvement of students' reading ability, 2) it made them engaged in the content of the story not only by promoting motivation and interest, but also by providing confidence in learning English, 3) it brought a sense of satisfaction and confidence to students who ended up being strongly motivated, 4) it helped students to have deeper understanding of the lesson, which led their voluntarily active class participation. Therefore, it was clear that digital stories provide ELL learners with powerful literacy learning opportunities.

There are several implications for the future study. First, more diverse teacher training programs are required in order for in-service teachers to catch the effective digital multimedia technologies suitable for the current students. Second, the improvement of multimedia facilities in a school is also needed to make teaching and learning environment better. Third, in a regular English class, a meaningful approach like digital storytelling should be considered for ELL learners to have a better communicate competence, without paying too much attention on the test and its score. By doing that, young ELL learners can have a strong sense of motivation to learn English for communicative purposes.

Acknowledgement: The researcher would like to thank and acknowledge Ms. Eunsun Jung and Mr. Kyung O Seok for their help on this study and the anonymous reviewers who have donated their time for the constructive comments and suggestions that have considerably improved the quality of the paper.

\section{References:}

Banaszewski, T. (2002). Digital storytelling finds its place in the classroom. Retrieved from http://www.infotoday.com/MMSchools/jan02/banaszewski.htm

Bull, G., \& Kajder, S. (2004). Digital storytelling in the language arts classroom. Learning \& Leading with Technology, 32(4), 46-49.

Burmark, L. (2004). Visual presentations that prompt, flash and transform. Media and Methods, 40(6), 4-5. http://dx.doi.org/10.1111/j.1754-8845.1999.tb00720.x

Burn, A., \& Reed, K. (1999). Digi-teens: Media literacies and digital technologies in the secondary classroom. English Education, 33(3), 5-20. http://dx.doi.org/10.1080/00094056.2009.10523090

Byrnes, J., \& Wasik, B. (2009). Picture this: Using photography as a learning tool in early childhood classrooms. Childhood Education, 85(4), 243-248. http://dx.doi.org/10.1080/19388079509558191

Chu, M. L. (1995). Reader response to interactive computer books: Examining literary responses in a non-traditional reading setting. Reading Research and Instruction, 34(4), 352-366.

Cradler, J., McNabb, M., Freeman, M., \& Burchett, R. (2002). How does technology influence student learning? Learning and Leading, 29(8), 46-49.

Judge, S., Puckett, K., \& Cabuk, B. (2004). Digital equity: New findings from the early childhood longitudinal study. Journal of Research on Technology in Education, 36, 383-396.

Kajder, S. B. (2006). Bringing the Outside In: Visual Ways to Engage Reluctant Readers. Portland, ME: Stenhouse Publishers. 
Yoon, $\mathrm{T}$.

Kajder, S., Bull, G., \& Albaugh, S. (2005). Constructing digital stories. Learning and leading with technology.

The Connected Classroom, 32(5), 40-42.

Lambert, J. (2002). Digital storytelling: Capturing lives, creating community. Berkeley, CA: Digital Diner Press.

Lowenthal, P. R. (2008). Online faculty development and storytelling: An unlikely solution to improving teacher quality. Journal of Online Learning and Teaching, 4(3), 349-356. Retrieved from http://jolt.merlot.org/vol4no3/lowenthal_0908.pdf

Marsh, J. (2006). Emergent media literacy: digital animation in early childhood. Language in Education, 20(6), 493-506. http://dx.doi.org/10.2167/le660.0

Mayer, R. E. (2003). Learning and instruction. Upper Saddle River, NJ: Prentice Hall.

Ohler, J. (2006). The world of digital storytelling. Educational Leadership, 63(4), 44-47.

Pierson, M. E. (2001). Technology integration practice as a function of pedagogical expertise. Journal of Research in Computing in Education, 33, 413-430.

Prensky, M. (2001a). Digital natives, digital immigrants. On the Horizon, 9(5), 1-6. Retrieved, from http://www.marcprensky.com/writing/Prensky\%20-\%20Digital\%20Natives,\%20Digital\%20Immigrants \%20-\%20Part1.pdf

Prensky, M. (2001b). Digital natives, digital immigrants, part II: Do they really think differently? On the Horizon, 9(6), 1-6. http://dx.doi.org/10.1108/10748120110424843

Pritchard, A. (2004). Introducing new students to ICT: Giving a purpose to it all. Active Learning in Higher Education, 5(3), 248-262. http://dx.doi.org/10.1177/1469787404046846

Robin, B. R. (2008). Digital storytelling: A powerful technology tool for the 21 st century classroom. Theory Into Practice, 47(3), 220-228. http://dx.doi.org/10.1080/00405840802153916

Sadik, A. (2008). Digital storytelling: A meaningful technology-integrated approach for engaged student learning. Educational Technology Research and Development, 56, 487-506. http://dx.doi.org/10.1007/s11423-008-9091-8

Sylvester, R., \& Greenidge, W. (2010). Digital storytelling: Extending the potential for struggling writers. The Reading Teacher, 63(4), 284-295. http://dx.doi.org/10.1598/RT.63.4.3

Tsou, W., Wang, W., \& Tzeng, Y. (2006). Applying a multimedia storytelling website in foreign language learning. Computers \& Education, 47, 17-28. http://dx.doi.org/10.1016/j.compedu.2004.08.013

Tucker, G. (2006). First person singular: The power of digital storytelling. Screen Education, 42, 54-58.

Vincent, J. (2006). Children writing: multimodality and assessment in the writing classroom. Literacy, 40(1), 51-57. http://dx.doi.org/10.1111/j.1467-9345.2006.00426.x

Ware, P. D. (2006). From sharing time to showtime! Valuing diverse venues for storytelling in technology-rich classrooms. Language Arts, 84(1), 45-54. 